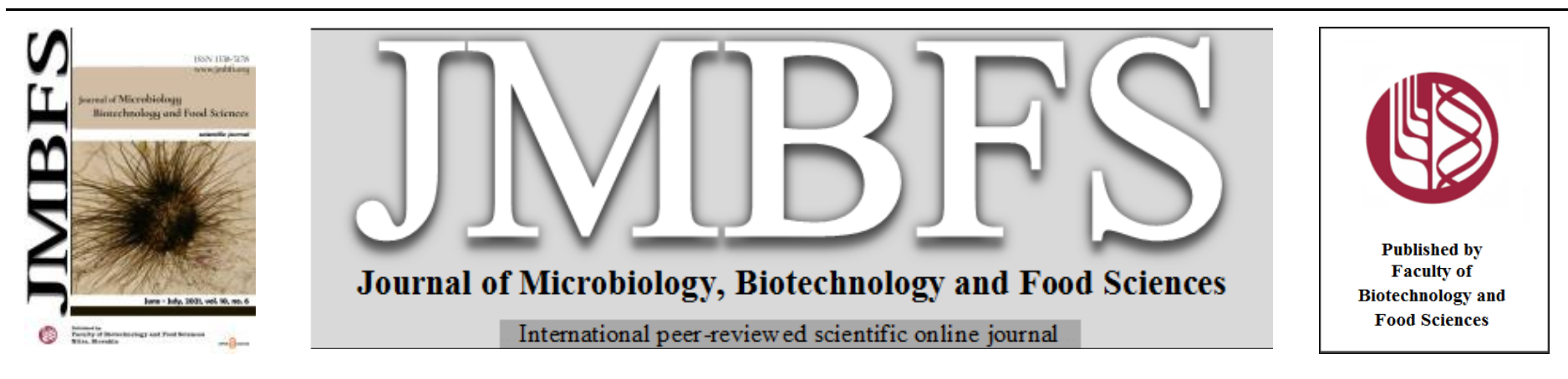

\title{
AFLATOXIGENIC FUNGI AND AFLATOXINS IN LOCALLY PROCESSED PEANUT BUTTER IN LAGOS, NIGERIA
}

\author{
Roseline Ekiomado Uzeh $*^{a, b}$ and Elizabeth Tolulope Adebowale ${ }^{a}$
}

Address(es):

${ }^{a}$ Permanent address: Department of Microbiology, Faculty of Science, University of Lagos, 100213, Lagos, Nigeria.

${ }^{b}$ Present address: Department of Biological Sciences, College of Science and Technology, Covenant University, Km. 10 Idiroko Road, Ota, Ogun, Nigeria.

*Corresponding author: roseline.uzeh@gmail.com, ruzeh@unilag.edu.ng, roseline.uzeh@ covenantuniversity.edu.ng

https://doi.org/10.15414/jmbfs.3546

\section{ARTICLE INFO}

Received 5. 8. 2020

Revised 21. 1. 2021

Accepted 2. 2. 2021

Published 1. 6. 2021

Regular article OPEN $\partial_{\text {ACCESS }}$

\begin{abstract}
Aflatoxin and the producing fungi are known contaminants of farm produce at pre-harvest, post-harvest storage and post-processing. This research was carried out to detect aflatoxigenic fungi and quantify aflatoxins in locally processed peanut butter. Forty-seven samples of peanut butter were purchased from vendors in different markets in Lagos, Nigeria. Fungal species were isolated by pour plate method and identified using cultural and microscopic characteristics. Aflatoxigenic fungi (Aspergillus flavus and A. parasiticus) were isolated from 14/47 (29.79\%) samples and they were screened for four aflatoxin genes (aflR, nor-1, ver-1, omt-1). Aflatoxin was quantified in samples with aflatoxigenic fungi using High Performance Liquid Chromatography with Ultra violet detection (HPLC-UV). Only seven (five A. flavus and two A. parasiticus) of the fourteen isolates screened had one or more aflatoxin genes with most isolates having nor-1 gene. Aflatoxin $\mathrm{B}_{1}$ was present in all the peanut butter while aflatoxins $\mathrm{B}_{2}, \mathrm{G}_{2}$ and $\mathrm{G}_{1}$ were present in $71.43 \%, 85.71 \%$, and $57.14 \%$ of the samples respectively. The peanut butter samples had total aflatoxin content ranging between $373.6 \mu \mathrm{g} / \mathrm{kg}-6741.6 \mu \mathrm{g} / \mathrm{kg}$, which is above the $20 \mu \mathrm{g} / \mathrm{kg}$ maximum permissible limit recommended by US FDA and $\leq 4 \mu \mathrm{g} / \mathrm{kg}$ by EU. Aflatoxin $\mathrm{B}_{1}$ content was $54.3 \mu \mathrm{g} / \mathrm{kg}-805.8 \mu \mathrm{g} / \mathrm{kg}$, and also far above the EU limit of $2 \mu \mathrm{g} / \mathrm{kg}$. The high concentration of aflatoxins and occurrence of aflatoxin $\mathrm{B}_{1}$ the most toxic aflatoxin, in all the peanut butter is of great concern to the health of consumers. Adequate sensitization on preventive measures especially avoidance of mouldy peanut kernels by sorting before use in the production of peanut butter should be encouraged.
\end{abstract}

Keywords: Aflatoxin; peanut butter; Aspergillus flavus; Aspergillus parasiticus

\section{INTRODUCTION}

Aflatoxins are mycotoxins known to be toxic, mutagenic, carcinogenic and immunosuppressant. They are secondary metabolites produced majorly by Aspergillus flavus and Aspergillus parasiticus. These fungi are common contaminants of cereals (maize, wheat, rice and oats), (Krnjaja et al., 2019) and nuts such as peanuts. Peanuts are rich in nutrients especially proteins, fats, carbohydrates, and minerals (Settaluri et al., 2012) and so will support fungal growth and aflatoxin production. Infection of peanut by aflatoxigenic fungi starts right from the farm before harvest through the storage period under conducive intrinsic and extrinsic factors. In the Tropics, humid storage conditions with high temperature support fungal growth. Contamination of peanut by Aspergillus section Flavi and aflatoxins could occur at any point along the supply chain (Norlia et al., 2019). Peanuts are the major raw materials used for production of peanut butter. Peanut and peanut products are among foods that have been found to be incriminated in aflatoxin contamination.

Siwela et al. (2011) investigated levels of aflatoxin in peanuts that can be passed over to peanut butter. They however discovered reduction in the level of aflatoxin at each processing stage bringing it to total reduction of $89 \%$ and with the highest reduction recorded during roasting and blanching/skinning of the peanut. Ndung'u et al. (2013) isolated Aspergillus niger, A. caeletus, A alliaceus, A. tamari, A. parasiticus, A. flavus (L and S strain) and Penicillium spp. from raw, roasted groundnut and peanut butter in Kenya. They also reported aflatoxin contamination in the nuts and butter which they attributed to the source of groundnuts and occurrence of defective nuts. High occurrence of aflatoxins was discovered in peanut and peanut butter in Zimbabwe (Mupunga et al., 2014). Yentur et al (2006) obtained aflatoxin level higher than that of the recommended Turkish Food Codex in their peanut butter samples.

Foods and feeds contaminated by aflatoxins affect human and animal health and also result in economic loss (Nazhand et al., 2020). Dietary exposure of humans to aflatoxins cause serious health problems worldwide and in some cases, it may lead to death, though the effect is usually cumulative. It has been known to cause acute hepatocellular carcinoma, liver cancer. Globally, aflatoxin has been reported to be responsible for the cause of $4.6 \%$ to $28.2 \%$ hepatocellular carcinoma yearly and aflatoxins have been found to be more prevalent in less developed countries in tropical and sub-tropical regions of the world (Liu and Wu (2010). Impaired digestion, slow rate of growth and teratogenic effect associated with congenital malformation have been reported as symptoms of aflatoxicosis (Sarma et al, 2017). Reye-like Syndrome was reported in Thailand, New Zealand, Czechoslovakia, the United States, Malaysia, -Venezuela, and Europe to be associated with aflatoxin (Bbosa et al., 2013).

In Nigeria, some researches have been carried out on mycotoxin contamination of peanut and peanut products. Oyedele et al. (2017) isolated moulds from $97.6 \%$ of the 84 groundnut samples from four agro-ecological zones in Nigeria. They isolated Penicillium, Fusarium and more of Aspergillus. They detected both fungal and bacterial metabolites and aflatoxins were the most abundant. Peanut cake commonly called 'kulikuli' was reported to contain 20 fungal metabolites with aflatoxins above the US FDA limit of $20 \mu \mathrm{g} / \mathrm{kg}$ in $90 \%$ of the samples (Ezekiel et al., 2012). Peanut butter in Nsukka, South East Nigeria was reported by Onyeke $\boldsymbol{e t}$ al. (2017) to contain total aflatoxin above the permissible level of $10 \mu \mathrm{g} / \mathrm{kg}$ set by $\mathrm{FAO} / \mathrm{WHO}$ for food meant for human consumption in developing countries and far exceeded the $4 \mu \mathrm{g} / \mathrm{kg}$ standard of the European Union but with aflatoxin $\mathrm{B}_{1}$ and $\mathrm{B}_{2}$ within permissible limits.

Lagos is a densely populated urban centre located in South West Nigeria where the populace depends largely on fast foods because of their metropolitan life style. Locally processed peanut butter bought both from road side and traditional markets is usually eaten with garden eggs. It is a delicacy which also serves as spread on bread. Peanut butter imported from other countries to Nigeria are retailed in super markets or super stores. The locally processed peanut butter is cheaper and easily accessible to consumers on the streets. The production process in local cottage industries do not adhere strictly to safety guidelines. Considering the association of aflatoxins with peanut, the raw material for production of peanut butter and the hazardous effect of aflatoxins this research work was carried out to determine the occurrence of aflatoxin producing fungi in locally produced peanut butter in Lagos, Nigeria for contamination with aflatoxins and presence of aflatoxin genes in the isolates. 


\section{MATERIALS AND METHODS}

\section{Sample collection}

A total of 47 samples of locally processed peanut butter (packaged in smal plastic containers) were bought from different markets in Lagos. The samples obtained were immediately labelled and transported to the laboratory for analysis. Samples were obtained from seven markets under five local government areas as shown in Table 1.

Table 1 Collection of samples

\begin{tabular}{lccc}
\hline S/N & Local government & Sample source & $\begin{array}{c}\text { Number of samples } \\
\text { obtained }\end{array}$ \\
\hline 1 & Lagos mainland & Oyingbo & 8 \\
2 & Alimosho & Iyana-ipaja & 5 \\
3 & Oshodi-isolo & Oshodi & 8 \\
4 & Shomolu & Bariga & 5 \\
5 & Eti-osa & Lekki phase one, & 21 \\
\hline
\end{tabular}

\section{Isolation and identification of fungi}

Ten grams of peanut butter was weighed into $90 \mathrm{ml}$ of sterile distilled water and homogenized. Using pour plate method, $1 \mathrm{ml}$ of resulting mixture was plated in duplicate on Potato Dextrose Agar (PDA) and incubated at $25^{\circ} \mathrm{C}$ for 5 days Colonies obtained were sub cultured on PDA to obtain pure cultures. Sterilized inoculating needle was used to cut small portion of fungal growth, placed on the middle of clean slide, few drops of lacto phenol blue were added and teased with the inoculating needle. It was carefully covered with a cover slip avoiding air bubbles production. It was then observed under $\times 40$ magnification of a light microscope.

Identification was based on microscopic examination, colony characteristics (colour, appearance, reverse colony colour appearance), using Pictorial atlas of soil and seed fungi (Watanabe, 2002) and Atlas of clinically important fungi (Sciortino, 2017)

\section{Detection of aflatoxin genes}

\section{DNA extraction}

The five A. flavus and nine A. parasiticus (14 in total) isolated from locally processed peanut butter were inoculated on fresh PDA and incubated at $25^{\circ} \mathrm{C}$ for $72 \mathrm{hrs}$. A small amount of each fungus was transferred into sterile mortar and crushed with pestle in Phosphate buffer solution (this preliminary step was to lyse the cell wall). A solution made up of $95 \mu 1$ of water, $95 \mu l$ of solid tissue buffer and $10 \mu \mathrm{l}$ of proteinase $\mathrm{K}$ was added and mixed thoroughly using a vortex mixer. It was then incubated at $55^{\circ} \mathrm{C}$ for $2 \mathrm{hrs}$ and centrifuged to remove insoluble debris. Then $200 \mu 1$ of supernatant was transferred to a tube and $400 \mu 1$ of genomic binding buffer was added to it. The mixture was transferred to a Zymo-spin ${ }^{\mathrm{TM}}$ IIC-XL column in a collection tube and centrifuged $(\geq 12000 \times \mathrm{g})$ for 1 minute, the collection tube was discarded with the flow through. To the column in a new collection tube, $400 \mu 1$ DNA Pre-wash buffer was added and centrifuged and the collection tube was emptied. Seven hundred micro litres $(700 \mu 1)$ of g-DNA wash buffer was added and centrifuged for 1 minute and the collection tube was emptied. Two hundred micro litres $(200 \mu l)$ of g-DNA wash buffer was added and centrifuged for 1 minute and the collection tube was discarded with the flow through. The Zymo-spin ${ }^{\mathrm{TM}}$ IIC-XL column was transferred to a $1.5 \mathrm{ml}$ Eppendorf tube and $50 \mu \mathrm{l}$ of elution buffer was used to elute the genomic DNA and was stored at $-20^{\circ} \mathrm{C}$ (Zymo Research Group, USA).

\section{Polymerase chain reaction $(\mathbf{P C R})$}

The Solis Biodyne 5X HOT FIREPol Blend Master mix was used. Primers used are as according to Scherm $\boldsymbol{e t}$ al. (2005) (Table 2). The $20 \mu 1$ reaction mixture used consisted of 1x Blend Master mix buffer (Solis Biodyne, Estonia), 2.0mM $\mathrm{MgCl}_{2}, 200 \mu \mathrm{m}$ of each deoxynucleoside triphosphates (dNTP) (Solis Biodyne, Estonia), 20pMol of each primer (BIOMERS, Germany), 2 units of hot FIREPol DNA polymerase (Solis Biodyne, Estonia), proofreading enzyme, $5 \mu 1$ of the extracted DNA, and was made up with sterile distilled water.

Peltier thermal cycler 100 (MJ Research) was used for thermal cycling. The initial denaturation was at $95^{\circ} \mathrm{C}$ for 15 minutes, followed by 35 cycles at $95^{\circ} \mathrm{C}$ for $30 \mathrm{~s}, 62^{\circ} \mathrm{C}$ for $1 \mathrm{~min}$. and $72^{\circ} \mathrm{C}$ for $1 \mathrm{~min}$. $30 \mathrm{~s}$. There was a final extension step at $72^{\circ} \mathrm{C}$ for $10 \mathrm{mins}$. The amplification product was separated on a $1.5 \%$ agarose gel and electrophoresis was carried out for $1 \mathrm{hr} 30 \mathrm{mins}$. at $80 \mathrm{~V}$. The DNA bands were visualized by staining with ethidium bromide. The 100bp DNA ladder was used as DNA molecular weight standard. The positive and negative controls used in this analysis were Aspergillus flavus ATCC 22546 and Penicillium fellutanum ATCC 48694 respectively.
Table 2 Aflatoxin primers used for PCR Amplification (Scherm et al., 2005)

\begin{tabular}{|c|c|c|c|}
\hline $\mathrm{S} / \mathrm{N}$ & Primer & Sequence & $\mathrm{bp}$ \\
\hline 1 & Nor-1F & $\begin{array}{l}5^{\prime} \text {-ACC GCT ACG CCG GCA CTC TCG } \\
\text { GCAC-3 }\end{array}$ & 400 \\
\hline 2 & Nor-1R & $\begin{array}{l}\text { 5'-GTT GGC CGC CAG CTT CGA CAC } \\
\text { TCC G-3 }\end{array}$ & 400 \\
\hline 3 & Ver-1F & $\begin{array}{l}\text { 5'-ATG TCG GAT AAT CAC CGT TTA } \\
\text { GAT GGC-3 }\end{array}$ & 895 \\
\hline 4 & Ver-1R & $\begin{array}{l}\text { 5'-CGA AAA GCG CCA CCA TCC ACC } \\
\text { CCA ATG-3' }\end{array}$ & 895 \\
\hline 5 & $O m t-1 \mathrm{~F}$ & $\begin{array}{l}\text { 5'-GGC CCG GTT CCT TGG CTC CTA } \\
\text { AGC-3' }\end{array}$ & 1232 \\
\hline 6 & Omt-1R & $\begin{array}{l}\text { 5'-CGC CCC AGT GAG ACC CTT CCT CG- } \\
3^{\prime}\end{array}$ & 1232 \\
\hline 7 & aflRF & $\begin{array}{l}\text { 5'-TAT CTC CCC CCG GGC ATC TCC } \\
\text { CGG-3' }\end{array}$ & 1032 \\
\hline 8 & aflRR & $\begin{array}{l}\text { 5'-CCG TCA GAC AGC CAC TGG ACA } \\
\text { CGG-3' }\end{array}$ & 1032 \\
\hline
\end{tabular}

\section{Extraction of aflatoxin from peanut butter samples}

Aflatoxin was extracted from the seven peanut butter samples which had isolates that possessed one or more aflatoxin genes. Twelve and half grams $(12.5 \mathrm{~g})$ of the sample in addition with $2.5 \mathrm{~g} \mathrm{NaCl}$ and $62.5 \mathrm{ml}$ of $70 \%$ methanol were homogenized in a blender for 2 minutes at high speed. The mixture was then filtered through No. 1 Whatman filter paper. Thirty millilitres $(30 \mathrm{ml})$ of water was added to $15 \mathrm{ml}$ of the filtrate and it was filtered again through a Millipore filter paper. Fifteen millilitres $(15 \mathrm{ml})$ of the second filtrate was passed through solid phase extraction (SPE) cartridge and then washed with $10 \mathrm{ml}$ of water. Aflatoxins were eluted with $1 \mathrm{ml}$ of ethanol and then $1 \mathrm{ml}$ of water (Stojanovska et al., 2013).

\section{Determination of aflatoxin concentration in peanut butter}

Aflatoxin concentration in locally made peanut butter samples and standards (Sigma-Aldrich) were determined using HPLC with UV detection. The seven samples with isolates that had one or more aflatoxin genes were those investigated for aflatoxin concentrations. The standards for aflatoxins $G_{2}, G_{1}, B_{2}$, and $\mathrm{B}_{1}$ had concentrations $1 \mu \mathrm{g} / \mathrm{ml}, 4 \mu \mathrm{g} / \mathrm{ml}, 1 \mu \mathrm{g} / \mathrm{ml}$, and $4 \mu \mathrm{g} / \mathrm{ml}$ respectively. The HPLC system consisted of a quad pump, degasser and a variable wavelength detector (Agilent Technologies, Germany). Aflatoxins were separated in HPLC column with mobile phase of methanol: water: acetonitrile (40:50:10\% respectively). The UV detection was at a wavelength of $365 \mathrm{~nm}$ and the flow rate was $0.7 \mathrm{ml} / \mathrm{min}$. The run time for each sample was about 10 minutes.

\section{RESULTS}

\section{Fungal contamination of peanut butter}

Out of the 47 samples of peanut butter investigated for fungal contamination, 33 $(70.21 \%)$ were contaminated with fungi from two main genera; Aspergillus and Rhizopus. A total of 42 fungal isolates was obtained. The fungal isolates identified include Rhizopus stolonifer, Aspergillus niger, Aspergillus parasiticus and Aspergillus flavus. Rhizopus stolonifer was the most prevalent at $50 \%$ (21/42), Aspergillus parasiticus 21\% (9/42), Aspergillus niger 17\% (7/42) and Aspergillus flavus 12\% (5/42) (Figure 1).

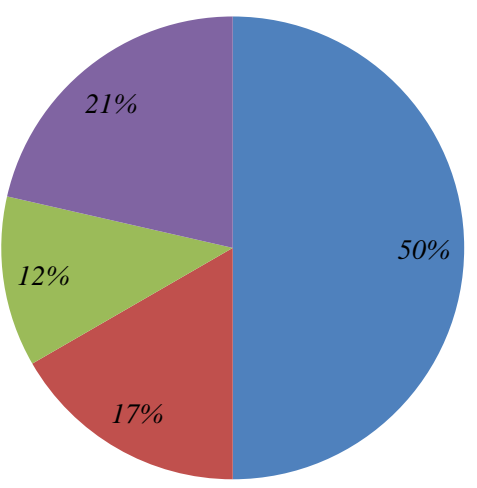

Rhizopus stolonifer

- Aspergillus niger

- Aspergillus flavus

- Aspergillus parasiticus

Figure 1 Prevalence of fungal isolates in locally processed peanut butter

Of greater importance in this study is that $14(29.79 \%)$ samples were contaminated by aflatoxigenic fungi (A. flavus and A. parasiticus) (Table 3). 
Table 3 Occurrence of fungal isolates in locally processed peanut butter

\begin{tabular}{ccccccc}
\hline S/N & Sample source & $\begin{array}{c}\text { Number of } \\
\text { samples with } \\
\text { mould growth }\end{array}$ & $\begin{array}{c}\text { Rhizopus } \\
\text { stolonifera }\end{array}$ & $\begin{array}{c}\text { Aspergillus } \\
\text { niger } \\
\text { (Occurrence) }\end{array}$ & $\begin{array}{c}\text { Aspergillus } \\
\text { flavus }\end{array}$ & $\begin{array}{c}\text { Aspergillus } \\
\text { parasiticus }\end{array}$ \\
\hline 1 & Lekki phase one & 2 & 1 & 2 & ND & ND \\
2 & Agungi & 3 & 1 & 1 & 1 & 1 \\
3 & Oyingbo & 5 & 2 & 1 & 1 & 1 \\
4 & Ajah & 10 & 8 & 1 & 3 & 5 \\
5 & Bariga & 4 & 3 & 1 & ND & ND \\
6 & Iyana-Ipaja & 4 & 3 & ND & ND & 1 \\
7 & Oshodi & 5 & 3 & 1 & ND & 1 \\
\hline
\end{tabular}

\section{Detection of aflatoxin genes}

Of the five Aspergillus flavus isolates identified in this study, two had the full complement of all four aflatoxin genes present, namely nor-1, ver-1, omt-1 and aflR. One had three with aflR absent, while the last two had only nor-1 present. Of the nine Aspergillus parasiticus isolates only two had nor-1 present while no genes were detected in the other seven isolates (Figures 2-5)

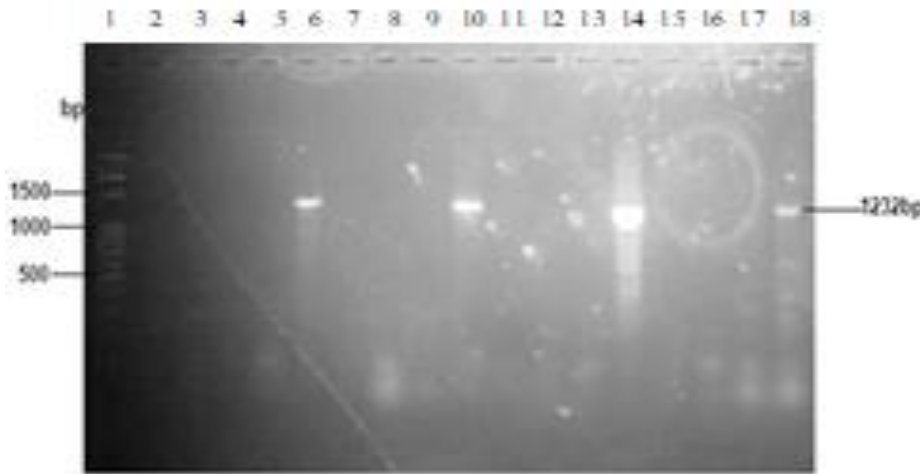

Figure 2 Detection of omt-1 gene; Lane 1, 100bp DNA ladder; Lane 2, negative control 1 (without genomic DNA); Lanes $6,10,14$, isolates that were positive for omt-1 gene; Lane 17, negative control 2 (Penicillium fellutanum ATCC 48694); Lane 18 positive control (Aspergillus flavus ATCC 22546).

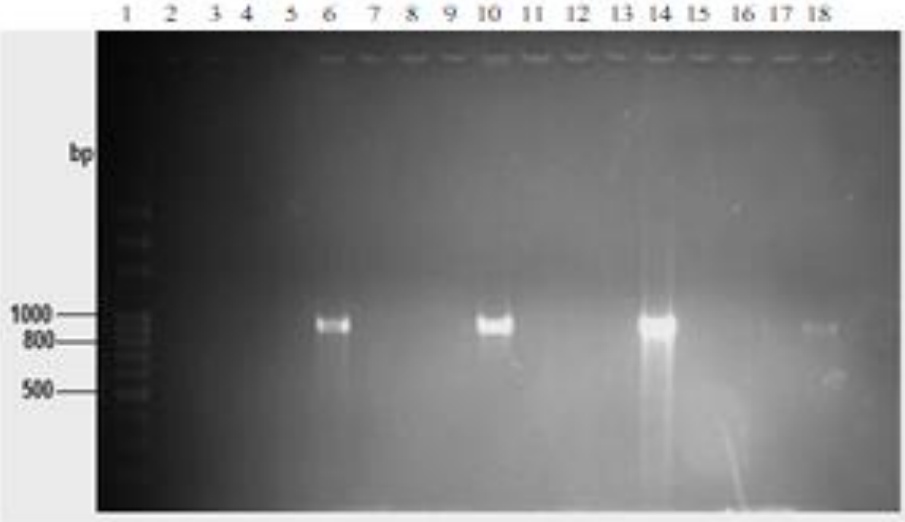

Figure 3 Detection of ver-1 gene; Lane 1, 100bp DNA ladder; Lane 2, negative control 1(without genomic DNA); Lanes $6,10,14$, isolates that were positive for ver-1 gene; Lane 17, Negative control 2 (Penicillium fellutanum ATCC 48694); Lane 18 positive control (Aspergillus flavus ATCC 22546).

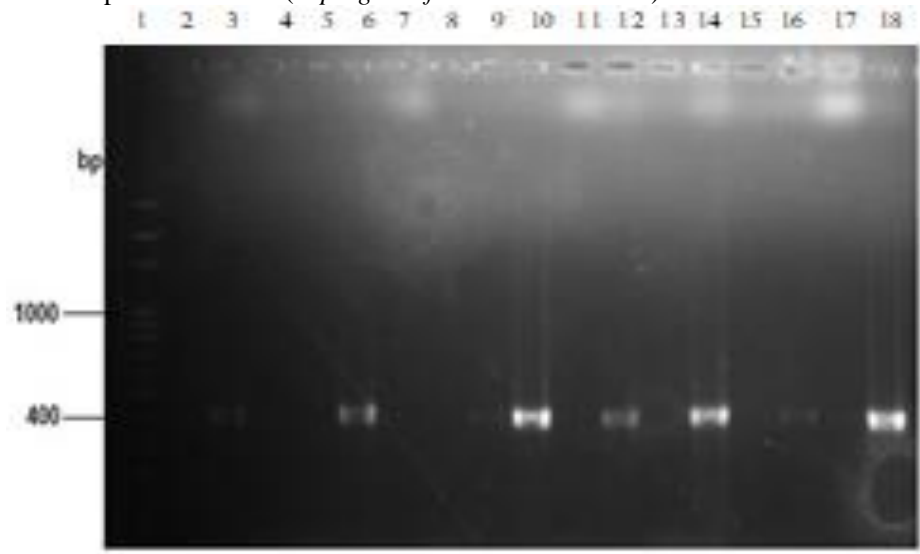

Figure 4 Detection of nor-1 gene; Lane 1, 100bp DNA ladder; Lane 2, negative control 1(without genomic DNA); Lanes 3, 6, 9, 10, 12, 14, 16 isolates that were positive for nor-1 gene; Lane 17, Negative control 2 (Penicillium fellutanum ATCC 48694); Lane 18 positive control (Aspergillus flavus ATCC 22546).

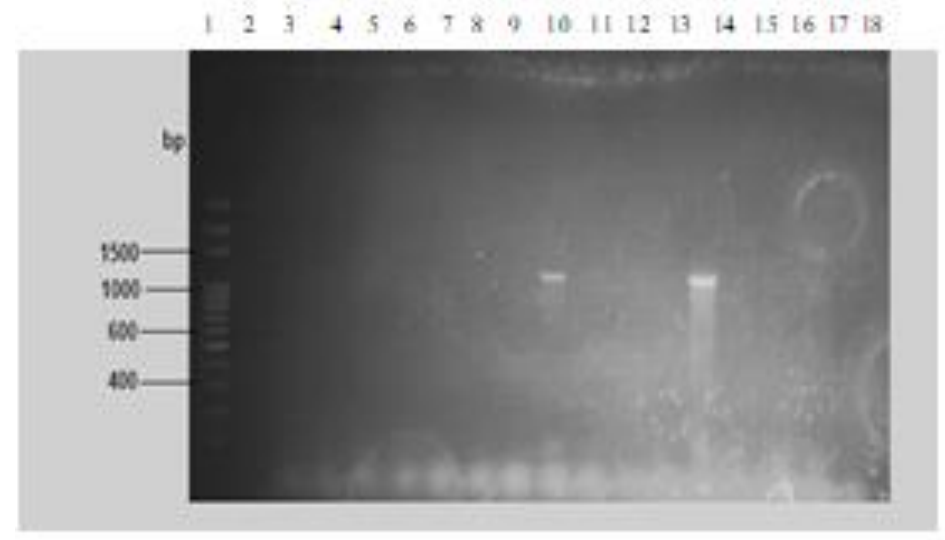

Figure 5 Detection of aflR gene; Lane 1, 100bp DNA ladder; Lane 2, negative control 1(without genomic DNA); Lanes 10, 14 isolates that were positive for aflR gene; Lane 17 negative control 2 (Penicillium fellutanum ATCC 48694); Lane 18 positive control (Aspergillus flavus ATCC 22546).

\section{Concentration of aflatoxins in peanut butter}

Aflatoxin was detected in the seven tested peanut butter samples. The concentration of aflatoxin $\mathrm{B}_{1}\left(\mathrm{AFB}_{1}\right)$, aflatoxin $\mathrm{B}_{2}\left(\mathrm{AFB}_{2}\right)$, aflatoxin $\mathrm{G}_{1}\left(\mathrm{AFG}_{1}\right)$ and aflatoxin $G_{2}\left(A F G_{2}\right)$ and their prevalence in the tested seven peanut butter samples varied between $3.526 \mu \mathrm{g} / \mathrm{kg}$ for aflatoxin $\mathrm{B}_{2}$ to $4284.6 \mu \mathrm{g} / \mathrm{kg}$ for aflatoxin $\mathrm{G}_{1}$ and $57.14 \%$ for aflatoxin $\mathrm{G}_{1}$ to $100 \%$ for aflatoxin $\mathrm{B}_{1}$ respectively (Table 4 ) The range of total aflatoxin concentration of the tested peanut butter was $373.6 \mu \mathrm{g} / \mathrm{kg}$ to $6741.6 \mu \mathrm{g} / \mathrm{kg}$ (Table 4 ).

Table 4 Concentration and prevalence of aflatoxins in locally processed peanu butter

\begin{tabular}{lcccccc}
\hline $\begin{array}{l}\text { Sample } \\
\text { number }\end{array}$ & Sample ID & $\mathrm{AFG}_{2}$ & $\begin{array}{c}\mathrm{AFG}_{1} \\
(\mu \mathrm{g} / \mathrm{kg})\end{array}$ & $\mathrm{AFB}_{2}$ & $\mathrm{AFB}_{1}$ & $\begin{array}{c}\text { Total } \\
\text { aflatoxins }\end{array}$ \\
\hline $\mathbf{7}$ & $\mathrm{a}$ & 1006.8 & 2656.6 & 41.20 & 805.8 & 4510.4 \\
18 & $\mathrm{~b}$ & 0.00 & 0.00 & 22.2 & 351.4 & 373.6 \\
22 & $\mathrm{c}$ & 3546 & 0.00 & 6.266 & 54.3 & 3606.57 \\
24 & $\mathrm{~d}$ & 1366 & 1310.4 & 92.2 & 397.8 & 3166.4 \\
25 & $\mathrm{e}$ & 2001 & 0.00 & 3.526 & 374.0 & 2378.53 \\
27 & $\mathrm{f}$ & 2110 & 667.0 & 0.00 & 167.6 & 2944 \\
44 & $\mathrm{~g}$ & 2257 & 4284.6 & 0.00 & 200 & 6741.6 \\
\hline \multicolumn{7}{c}{} \\
\hline & Prevalence & & & & \\
\end{tabular}

\section{DISCUSSION}

In this study, $14(29.79 \%)$ of the 47 samples of locally processed peanut butter from different zones in Lagos, Nigeria were contaminated with aflatoxigenic fungi (A. parasiticus and A. flavus). This is similar to the result reported by Mupunga et al. (2014) who isolated aflatoxigenic fungi from $3(27 \%)$ of their 11 peanut butter samples in Zimbabwe. The peanuts which served as raw materia for production of the peanut butter could have been contaminated with aflatoxigenic fungi and carried over to the peanut butter. In Nigeria the local production of peanut butter is done in cottage industries. Hazard Analysis and Critical Control Points (HACCP) have not been established in the production process. Therefore, fungal contaminants can set in along the processing line. Roasting of peanut is one of the steps involved in peanut butter production. However, there is no evidence of adequate monitoring of roasting temperature which may have helped to eliminate at least the vegetative forms of fungal contaminants although fungal spores could germinate later. Fungal contaminants may also have been introduced from the spices. There may have been post 
processing contamination of the peanut butter by fungi during packaging or hawking from the environment.

Two of the A. flavus strains had the four aflatoxin genes (nor-1, ver-1, omt-1 and aflR), 1 strain had 3 genes except aflR while 2 strains each of A. flavus and $A$ parasiticus had only nor-1 gene. This was as opposed to the work carried out by Davari et al. (2015) on animal feedstuffs in Iran from which all aflatoxigenic isolates had the four genes. Different strains may have been isolated from both studies. In our study, two strains of Aspergillus flavus produced $\mathrm{AFB}_{1}, \mathrm{AFB}_{2}$ $\mathrm{AFG}_{1}$, and $\mathrm{AFG}_{2}$, one produced $\mathrm{AFG}_{2}, \mathrm{AFB}_{2}, \mathrm{AFB}_{1}$, another one produced $\mathrm{AFG}_{2}, \mathrm{AFG}_{1}, \mathrm{AFB}_{1}$ and yet another produced $\mathrm{AFB}_{1}, \mathrm{AFB}_{2}$. Each of the two Aspergillus parasiticus produced $\mathrm{AFG}_{2}, \mathrm{AFB}_{2}, \mathrm{AFB}_{1}$ and $\mathrm{AFG}_{2}, \mathrm{AFG}_{1}, \mathrm{AFB}$ respectively. This can be compared with the work of Gherbawy et al. (2016) where their aflatoxigenic Aspergillus flavus and Aspergillus parasiticus isolates produced the four aflatoxins $\left(\mathrm{AFB}_{1}, \mathrm{AFB}_{2}, \mathrm{AFG}_{1}\right.$, and $\left.\mathrm{AFG}_{2}\right)$ in a similar pattern. The total aflatoxin concentration of all tested samples ranged from $373.6 \mu \mathrm{g} / \mathrm{kg}$ $6741.6 \mu \mathrm{g} / \mathrm{kg}$ which is above the $20 \mu \mathrm{g} / \mathrm{kg}$ maximum permissible limit by US/FDA and the $\leq 4 \mu \mathrm{g} / \mathrm{kg}$ limit of the European Union (EU). This result differs from the 6.1 to $247 \mathrm{ng} / \mathrm{g}$ obtained from peanut butter in Zimbabwe by Mupunga et al (2014). Of all the aflatoxins analysed, $\mathrm{AFB}_{1}$ was the most prevalent $(100 \%)$ which is similar to the $90 \%$ contamination of $\mathrm{AFB}_{1}$ in peanut butter samples in South Africa reported by Kamika et al., (2014). In our study, $\mathrm{AFB}_{1}$ concentration ranged from $54.3 \mu \mathrm{g} / \mathrm{kg}-805.8 \mu \mathrm{g} / \mathrm{kg}$ which is above the EU maximum limit of $\leq 2 \mu \mathrm{g} / \mathrm{kg}$. This is in contrast with the $20 \mu \mathrm{g} / \mathrm{kg}$ to $10,740 \mu \mathrm{g} / \mathrm{kg}$ level of $\mathrm{AFB}_{1}$ observed by Njoroge et al. (2016) over a three-year period in Zambia. We however obtained prevalence of $87.71 \%, 71.43 \%$ and $57.14 \%$ for $\mathrm{AFG}_{2}, \mathrm{AFB}_{2}$ and $\mathrm{AFG}_{1}$ respectively. The high level of aflatoxins in the peanut butter may be possibly due to such level in peanuts which served as the major raw material. Local producers of peanut butter in Nigeria may not be aware of the dangers of aflatoxin contamination both in peanut and peanut butter. Aflatoxin B is the most carcinogenic of all mycotoxins. It's association with hepatocellular carcinoma in liver and the likely synergy between the effect of hepatitis B virus and aflatoxins was reported by Mably et al. (2005).

\section{CONCLUSION}

This study has revealed contamination of locally processed peanut butter in Lagos, Nigeria with presence of aflatoxigenic fungi and aflatoxins above recommended limits. Adequate sensitization of the local producers against the use of mouldy peanuts is recommended. Our results from Lagos will help to broaden existing information on aflatoxins in Nigeria and the African continent at large.

Competing interest: None to declare

This research did not receive any grant from funding bodies.

\section{REFERENCES}

Bbosa, G. S., Kitya, D., Lubega, A., Ogwal-Okeng, J., Anokbonggo, W. W., and Kyegombe, D. B. (2013). Review of the Biological and Health Effects of Aflatoxins on Body Organs and Body Systems. Aflatoxins - Recent Advances and Future Prospects. https://doi.org/10.5772/51201

Davari, E., Mohsenzadeh, M., Mohammadi, G. H., and Rezaeian-Doloei, R. (2015). Characterization of aflatoxigenic Aspergillus flavus and A. parasiticus strain isolates from animal feedstuffs in north eastern Iran. Iranian Journal of Veterinary Research, 16(2), 150-155.

Ezekiel, C. N., Sulyok, M., Warth, B., Odebode, A. C., and Krska, R. (2012) Natural occurrence of mycotoxins in peanut cake from Nigeria. Food Control, 27(2), 338-342. https://doi.org/10.1016/j.foodcont.2012.04.010

Gherbawy, Y. A., Shebany, Y. M., and Alharthy, H. F. (2016). Molecular characterization of aflatoxigenic aspergilli-contaminated poultry and animal feedstuff samples from the Western region of Saudi Arabia. Italian Journal of Food Science, 28, 32-42. https://doi.org/10.14674/1120-1770/ijfs.v455

Kamika, I., Mngqawa, P., Rheeder, J. P., Teffo, S. L., and Katerere, D. R. (2014) Mycological and aflatoxin contamination of peanuts sold at markets in Kinshasa, Democratic Republic of Congo, and Pretoria, South Africa. Food Additives \&
Contaminants:
Part
B,
$7(2)$,
$120-126$

https://doi.org/10.1080/19393210.2013.858187

Krnjaja, V., Mandić, V., Stanković, S., Obradović, A., Vasić, T., Lukić, M. and Bijelić, Z. (2019). Influence of plant density on toxigenic fungal and mycotoxin contamination of maize grains. Crop Protection, 116, 126-131. https://doi.org/10.1016/j.cropro.2018.10.021

Liu, Y., and Wu, F. (2010). Global burden of aflatoxin-induced hepatocellular carcinoma: A risk assessment. Environmental Health Perspectives, 118(6), 818-824. https://doi.org/10.1289/ehp.0901388

Mably, M., Mankotia, M., Cavlovic, P., Tam, J., Wong, L., Pantazopoulos, P., ... Scott, P. M. (2005). Survey of aflatoxins in beer sold in Canada. Food Additives and Contaminants, 22(12), 1252-1257. https://doi.org/10.1080/02652030500241884

Mupunga, I., Lebelo, S. L., Mngqawa, P., Rheeder, J. P., and Katerere, D. R. (2014). Natural occurrence of aflatoxins in peanuts and peanut butter from
Bulawayo, Zimbabwe. Journal of Food Protection, 77(10), 18141818. https://doi.org/10.4315/0362-028x.jfp-14-129

Nazhand, A., Durazzo, A., Lucarini, M., Souto, E. B., and Santini, A. (2020) Characteristics, occurrence, detection and detoxification of aflatoxins in foods and feeds. Foods, 9(5), 644. https://doi.org/10.3390/foods9050644

Ndung'u, J., Makokha, A., Onyango, C., Mutegi, C., Wagacha, J., Christie, M. and Wanjoya, A. (2013). Prevalence and potential for aflatoxin contamination in groundnuts and peanut butter from farmers and traders in Nairobi and Nyanza provinces of Kenya. Journal of Applied Biosciences, 65 https://doi.org/10.4314/jab.v65i0.89579

Njoroge, S. M. C., Matumba, L., Kanenga, K., Slambi, M., Waliyar, F., Maruwo, J. and Monyo, E. S. (2016). A case for regular aflatoxin monitoring in peanut butter in Sub-Saharan Africa: Lessons from a 3-year survey in Zambia. Journal of Food Protection, 79(5), 795-800. https://doi.org/10.4315/0362-028X.JFP-15542

Norlia, M., Jinap, S., Nor-Khaizura, M. A. R., Radu, S., Samsudin, N. I. P. and Azri, F. A. (2019). Aspergillus section Flavi and aflatoxins: Occurrence, detection, and identification in raw peanuts and peanut-based products along the supply chain. Frontiers in Microbiology, https://doi.org/10.3389/fmicb.2019.02602

Onyeke, C. C., Obasi, E. J., Ajuziogu, G. C., Onoja, U. S., Osibe, D. A., Nweze E. I., Ikwuagwu, O. E. and Eyo, J. E. (2017). Aflatoxins composition of maize (Zea mays L.), guinea corn (Sorghum bicolor L.), cold paps and peanut (Arachis hypogea) butter in Nsukka, Nigeria. Journal of Basic Pharmacology and Toxicology, 1(3), 18-22

Oyedele, O. A., Ezekiel, C. N., Sulyok, M., Adetunji, M. C., Warth, B., Atanda O. O. and Krska, R. (2017). Mycotoxin risk assessment for consumers of groundnut in domestic markets in Nigeria. International Journal of Food Microbiology, 251, 24-32. https://doi.org/10.1016/j.ijfoodmicro.2017.03.020

Sarma, U. P., Bhetaria, P. J., Devi, P. and Varma, A. (2017). Aflatoxins: Implications on health. Indian Journal of Clinical Biochemistry, 32 (2), 124-133. https://doi.org/10.1007/s12291-017-0649-2

Scherm, B., Palomba, M., Serra, D., Marcello, A. and Migheli, Q. (2005). Detection of transcripts of the aflatoxin genes aflD, aflO, and aflP by reverse transcription-polymerase chain reaction allows differentiation of aflatoxinproducing and non-producing isolates of Aspergillus flavus and Aspergillus parasiticus. International Journal of Food Microbiology, 98(2), 201-210. https://doi.org/10.1016/j.ijfoodmicro.2004.06.004

Sciortino, C. V. (2017). Atlas of Clinically Important Fungi. https://doi.org/10.1002/9781119069720

Settaluri, V. S., Kandala, C. V. K., Puppala, N. and Sundaram, J. (2012). Peanuts and their nutritional aspects $-\mathrm{A}$ review. Food and Nutrition Sciences,

03(12), 1644-1650. https://doi.org/10.4236/fns.2012.312215

Siwela, A. H., Mukaroa, K. J. and Nziramasanga, N. (2011). Aflatoxin carryover during large scale peanut butter production. Food and Nutrition Sciences, 02(02), 105-108. https://doi.org/10.4236/fns.2011.22014

Stojanovska-Dimzoska, B., Hajrulai-Musliu, Z., Dimitrieska-Stojkovic, E. Uzunov, R. and Sekulovski, P. (2013). Occurrence of aflatoxins in peanuts and peanut products determined by liquid chromatography with fluorescence detection. Proceedings for Natural Sciences Matica Srpska, (124), 27-35 https://doi.org/10.2298/zmspn1324027s

Watanabe, T. (2002). Pictorial Atlas of Soil and Seed Fungi. https://doi.org/10.1201/9781420040821

Yentür, G., Er, B., Gür Özkan, M. and Bayhan Öktem, A. (2006). Determination of aflatoxins in peanut butter and sesame samples using high-performance liquid chromatography method. European Food Research and Technology, 224(2), 167-170. https://doi.org/10.1007/s00217-006-0310-4 